\title{
Investigation of legacy methane seepage into freshwater food webs using novel applications in Stoney Creek, New Brunswick
}

\author{
Ifedayo Abel-Adegbite ${ }^{\mathrm{a}}$, Michelle Gray ${ }^{\mathrm{b}}$, Brian Hayden ${ }^{\mathrm{a}}$
}

Legacy oil, gas, and coalfields in the Maritime region have emitted methane into the surrounding ecosystem for more than 100 years. Methane escaping from these legacy sites may have effects on the surrounding terrestrial and aquatic environments. I investigated whether methane could be detected entering streams via groundwater inputs in an area with abandoned and active oil and gas wells. Introduction of a foreign compound, such as methane, could act as an environmental stressor and could impact the local food web starting at the lowest trophic level. I predicted that if methane was entering freshwater streams and being incorporated into the food web, it would be evident in the stable isotopes of consumers and prey. Methane would have a distinct isotopic carbon signature and could be traced through the various biotic compartments. This project focuses on the novel application of using a small thermal imaging camera to help detect subsurface groundwater inputs into the stream for site selection. Using this temperature sensing technology, I found and selected 5 suspected groundwater sources flowing into the stream channel. I collected biofilm (e.g. bacteria, algae, diatoms) and benthic macroinvertebrate from both upstream and downstream of each suspected groundwater input site. With small streams and low summer water levels, I was unable to adequately sample the fish community. Stable isotope analysis of biofilm and benthic macroinvertebrates did not show obvious incorporation of methane into the food web, though some values were suspect. Additionally, I completed a diatom community assessment applying the Eastern Canadian Diatom Index (IDEC) as a measure of the biological integrity of streams and were able to show that the study sites in the Stoney Creek region are currently considered "slightly polluted", with a few select locations bordering on "polluted". Although these techniques and tools did show the incorporation of methane in the food web at Stoney Creek, the combination of inexpensive tools can be employed in the investigation of methane at other sites. This study serves as an exploration and application of tools and techniques that have not previously been applied in this context.

Keywords: Legacy methane, Stable isotopes, Eastern Canadian Diatom Index (IDEC)

\section{Introduction}

\section{Methane emissions}

Methane, a major greenhouse gas, is a public concern with several implications for the environment. Its ability to trap heat in the earth's atmosphere has been a major factor in contributing to global warming over the past decades. It has been estimated that approximately $540 \mathrm{Tg}\left(1 \mathrm{Tg}=10^{12} \mathrm{~g}\right)$ of $\mathrm{CH}_{4}$ is released annually from anthropogenic sources (Cicerone and Oremland 1988). Methane emissions are primarily fostered through the production and transport of coal, natural gas, agriculture, and landfill waste. Fossil fuels, which formed approximately over the course of 4 billion years through geological processes from decayed biomass, are the source of today's natural gas (thermogenic methane). Interestingly, humans' use of fossil fuel gas has been a major contributor to atmospheric methane. In fact, human combustion of fossil fuel and natural gas has contributed to $33 \%$ of total flux methane emission in the past two decades (Bousquet et al. 2006). Canada, one of the leading countries in clean energy initiatives, hopes to reduce oil and gas methane emissions by $40 \%$ by 2025 . At the moment, several strategies are currently being explored in the mitigation of methane emission (Konschnik and Jordaan 2018).

Abandoned oil wells from inactive drilling sites are one of the main avenues Canada is exploring for mitigation of methane since they create a potential for subsurface methane migration. Legacy methane escaping from various old well sites across North America has contributed significantly to total methane emissions from the energy sector. Researchers recently concluded that legacy methane escaping from old well sites across North America makes up 4-7\% of total methane emission from the energy sector (Kang et al 2014). The oil and gas sector's contribution to atmospheric methane concentrations is becoming an increasingly prevalent issue in climate policy (Konschnik and Jordaan 2018). Furthermore, methane escaping from these legacy sites may also have effects on the surrounding environments via groundwater into nearby streams or rivers.

\section{Methane in New Brunswick}

New Brunswick (NB) is one of the oldest oil producing provinces in the world with oil wells dating back as far as 1858 (Rivard et al. 2013). The lower Carboniferous Albert formation region near Stoney Creek, south of Moncton, has attracted several major oil companies over the years e.g Aldis Petroleum, Eastern Canada Petroleum and Irving Petroleum Ltd. (St. Peter 2000). The accessibility and abundance of natural gas has kept it an active site with continuous drilling since 1858 . With better understanding of the consequences of unsafe drilling, several safeguards have been implemented to reduce environmental risk. The first major policies came out at 1952 when the government enforced properly encased oil wells and several safety features (Ide et al. 2006). At the time, New Brunswick did not have its own regulatory institution for petroleum and energy, so established regulatory bodies such as American Petroleum Institute(API) and Alberta Energy Resources Conservation Board (ERCB) practices were followed. Oil wells sealed after 1952 are considered to be more effective due to higher standard requirements from API and ERCB from the time period: for example, stronger chemical additives were required in the cement material used for sealing Oil wells (National Petroleum Council 2011). However, older abandoned oil wells prior to 1952 that were sealed or 
abandoned before the implementation of the new regulations were not required to undergo proper sealing requirements. In New Brunswick, $85 \%$ of 302 total drilled wells are in a suspended or abandoned state, and $60 \%$ of the total were abandoned over 70 years ago (St. Peter 2000). Structural weakness in improperly sealed oil wells can lead to cracks and leaks in the casing of the wells (King and King 2013). Commercialized drilling of bedrock formation originating from the Carboniferous era has produced natural gas and various fossil fuels and has impacted the naturally occurring aquifers and groundwater (Osborne et al. 2011). Gas migration that does not reach the surface cannot be detected unless it contaminates groundwater and is not monitored by operators and reported to regulatory agencies (Bachu 2017). Concerns about groundwater contamination from natural gas drilling have been a major controversy over the past decades (NB Department of Environment and Local Government 2017). This paper addresses methane as a chemical contaminant because prolonged exposure to the hydrocarbon may have an induced toxic effect even at low dosage especially to organisms that do not metabolize the compound (Freedman 1995). Methane from groundwater sources entering these streams could be released as bubbles or, diffuses into ground water seepage (Etiope et al. 2016). Under specific conditions (e.g high temperature and pressure) methane can combine with water to form a $\mathrm{CH}_{4}$ hydrate, leading to the formation of dissolved methane (McPhillips et al. 2014). Seepage into nearby streams and rivers can be detected easily due to groundwater's distinct lower temperature levels (Duarte et al. 2006, Johnson et al. 2008). it is essential to utilize a device that can detect these groundwater seeps entering the streams in order to find potential methane inputs. Detection of these inputs can lead to further assessments; however, utilized devices must be inexpensive and relatively easy to use.

\section{Stable isotopes}

Methane derived carbon contribution into the food web has been studied in great detail with the use of stable isotopes (Ben-David and Flaherty 2012, Fry 2006, Withicar 1999). Stable isotopes of an element differ in the atomic mass but with similar chemical bonding characteristics. This physical mass differences lead to segregation between a heavy isotope form and a light isotopic form (Ben-David and Flaherty 2012). Some organisms undergo various physiological and biological processes where they can discriminate between which form of isotope to use (isotopic fractionation). For example, $\mathrm{CO}_{2}$ fixation in photosynthesis Calvin and rubisco cycle (i.e. C3 plants) undergo fractionation thereby assimilating the ${ }^{12} \mathrm{C}$ lighter isotopes compared to ${ }^{13} \mathrm{C}$ heavier isotopes ( $-25 \%$ to $35 \%$ ), while $\mathrm{C} 4$ plants that utilize Hack-Slack cycle fractionation favors the enriched isotopic form (15\%o to - $11 \%$ ). Ecologists use the difference between isotope ratio as a natural tracer to dissect the feeding pattern and food resources between the consumer and the producer (Fry 2006). Samples with a lower ratio of ${ }^{13} \mathrm{C}$ to ${ }^{12} \mathrm{C}$ isotopes relative to a standard will yield a more $\delta{ }^{13} \mathrm{C}$ negative value (depleted) while samples with higher ratios of ${ }^{13} \mathrm{C}$ to ${ }^{12} \mathrm{C}$ will have a more $\delta{ }^{13} \mathrm{C}$ positive value(enriched).

The isotopic signature of a consumer is similar to the isotopic signature of its food source (Ben-David and Flaherty 2012). Therefore, when an organism which normally consumes an enriched ${ }^{13} \mathrm{C}$ food source switches diet to a ${ }^{13} \mathrm{C}$ depleted food source, the isotopic value of the organism shifts slightly towards the negative end of the scale. The more the organism feeds on a ${ }^{13} \mathrm{C}$ depleted carbon source, the more depleted carbon accumulates in the organism's tissue, which shifts the isotopic value closer to the depleted source's isotopic value. Analyzing stable isotopes using mass spectrometry, a linear correlation of consumer and preys in the food web can be found through bioaccumulation of ${ }^{13} \mathrm{C}$ and ${ }^{15} \mathrm{~N}$ in their diet.

Methane is a potential source of carbon in the ecosystem and has a distinct isotopic signature. Several studies have reported depleted $\delta{ }^{13} \mathrm{C}$ value as low as (-60\%) indicative of consumers feeding on methanotrophic organisms (Kiyashko et al. 2001, Whiticar et al. 1986, Jones and Grey 2011). At the lowest level in the food web, methane will be consumed by methanotrophs as a source of energy. Carbon from $\mathrm{CH}_{4}$ can be assimilated into microbacteria during the oxidation process in methanotrophy. In the food web, methane oxidizing bacteria (MOB) are a source of carbon for primary consumers. Methane oxidizing bacterial (MOB) can be ingested by benthic invertebrates which act as an intermediary in carbon energy to biomass in the aquatic ecosystem. For example, Chironomidae are important detritivores widely known as conduits of carbon transfers trophically and these benthic invertebrates feed on MOB. In a survey of 87 lakes, Jones et al. (2008) estimated that one-third of lakes which contained Chironomidae larvae derive $40 \%-70 \%$ of their carbon from methane. The assimilation of MOB's carbon in Chironomidae gives a distinct isotopic signature relative to other food sources. The carbon biomass from methanotrophs is then passed through the food web which forms a unique isotopic value that can be traced (Whiticar 1999).

\section{Diatom assessment in Canada}

Thermogenic methane from buried organic matter emitting through abandoned wells may enter the aquatic environment as a possible stressor. Methane diffusing into the streams for a prolonged period can potentially impact lifeforms living in the aquatic habitat by directly influencing species richness or resource availability which in turn may modify important ecosystem function (Fleeger et al. 2003). Organisms living in aquatic streams near oil wells may act as a surface indicator of the wellbeing of an ecosystem. For example: in CABIN (Canadian Aquatic Biomonitoring Network) assessments, benthic macroinvertebrates have been used at various site location to monitor for environmental change due to human impact. Although, this biomonitoring has been utilized successfully in assessing an aquatic ecosystem under anthropogenic stress, it's only effective at a higher trophic level (e.g. benthic macroinvertebrates). It is important to utilize new field studies that includes investigating effects on the lowest trophic level where impacts are faster, easier to detect, and have a better chance of being reversed or mitigated.

One tool that can be incorporated into the analysis to detect the effect of a foreign input in the aquatic ecosystem involves the use diatom assemblages. Diatoms located at the lowest trophic level are used in ecological assessment to describe the ecosystems health. Most organisms used in biomonitoring as indicators of streams integrity respond slowly to changes; however, due to diatoms' position and nutritional needs these algae are able to show strong responses in a quick and predictable manner to effects of pollutant and other forms of stress (McCormick 1994). Over the years, diatoms have 
been used as bioindicators in climate change (Antoniades and Douglas 2002), forensic science (Kristic et al. 2002), and more recently water quality assessment (Lavoie et al. 2014). Several countries around the world have implemented diatom-based indices as a supplementary tool to enhance their water quality assessment. For example, the EU Water Framework Directive (Poikane et al. 2014, Kelly and Whitton 1995), and the U.S. Environmental Protection Agency's Environmental Monitoring and Assessment Program-Surface Waters (EMAP-SW) (Dixxit and Smol 1994) have included diatom-based indices in their environmental legislation statutory requirements. Canada, however, has not integrated this effective tool into a nationwide water quality assessment program despite the development of the regional diatom-based indices (IDEC: Indice Diatomées de l'Est du Canada) (Lavoie et al. 2014). IDEC was developed specifically for eastern Canada rivers and compiles the responses of the community to local stressors in an aquatic ecosystem into a value which can be compared to a reference site (Lavoie et al. 2006). The more recent IDEC 3.0 has proven itself successful over the years and has been incorporated only into Quebec's biomonitoring water assessment program (Lavoie et al. 2014). The latest version of this assessment might be effective in determining if a change is occurring at the diatom level by the introduction of a contaminant such as methane.

\section{Hypothesis}

Introduction of a foreign compound, such as methane, could impact the local food web starting at the lowest trophic level. If the Stoney Creek sites was contaminated with methane, Firstly, it is possible to detect potential methane input through groundwater seeps using a thermal camera. Secondly, if seeps are contaminated with methane, it is predicted that there will be an abundance of methanotrophs downstream of seepage point, which will incorporate methane's isotopic signature into the food web and can be traced using stable isotopes. Lastly, the sites' diatom community can be accessed using the Eastern Canadian Diatom Index (IDEC) to measure the biological integrity of streams at different Stoney Creek, and it is predicted that there will be a decrease in IDEC value downstream all sites reflecting a more stressed condition if methane is entering via groundwater. Any environmental assessment methods used should be relatively inexpensive, easy to apply and understandable, and provide reliable results to be used at other sites

\section{Methods}

\section{Site selection}

The Stoney Creek region, situated in Moncton NB, has 70 abandoned sites and 12 active gas wells currently operating in the region (Figure 1) The search to find suitable study sites was concentrated around streams located near oil well sites. In order to find areas that may be influenced by groundwater, I used two temperature-sensing technologies while walking sections of Stoney Creek and tributaries. The first was a Seek Thermal camera (www.thermal.com; $\pm 1-2^{\circ} \mathrm{C}$ ), mounted on a mini-iPad, and the second was a Etekcity thermal infrared gun $\left( \pm 3-4^{\circ} \mathrm{C}\right)$. During the stream walks, both devices were pointed at the surface of the water approximately $1 \mathrm{~m}$ above stream surface.

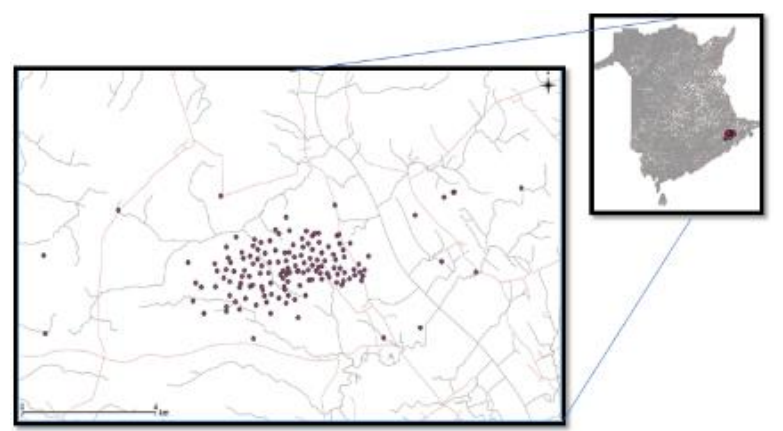

Figure 1. Map of the area of concern in Stoney Creek, NB, with purple dots indicating current and abandoned wells indicated.

In order to maximize the detection of cold-water inputs, the stream walks were conducted in the late morning and early afternoon when the temperature difference between groundwater and regular stream water would be maximized. Seven particular sites had significant temperature changes measured, from which I selected five stations for the food web study to maximize spatial coverage (Table 1 and Figure 2). Although the stream temperature changes were detected by the SEEK thermal camera, actual temperature recordings were taken from YSI Promodel 2030. Dissolved oxygen $\mathrm{pH}$ and YSI was calibrated before usage on all sites. I collected biofilms and macroinvertebrates samples approximately 10 meters upstream and downstream of the thermal anomalies. Temperature recordings, $\mathrm{pH}$, and other physical stream data were taken where samples were collected (Table 2). To avoid stream disturbance, the downstream station was sampled first, followed by the upstream station at each study sites.

Table 1. Site location including observed physical characteristics of 5 thermal spots identified for cold water seeps. Physical and biological data was collected both upstream and downstream of each site ( $\mathrm{SC}=$ Stoney Creek).

\begin{tabular}{ccccc}
\hline Site name & Geographiclocation & $\begin{array}{c}\text { Average } \\
\text { stream width }\end{array}$ & $\begin{array}{c}\text { Average } \\
\text { stream depth }\end{array}$ & Canopy coverage \\
\hline $\mathrm{SC} 01$ & $\mathrm{~N}^{\circ} 5^{\circ} 58.154^{\prime} \mathrm{W} 64^{\circ} 43.576^{\prime}$ & $1 \mathrm{~m}$ & $12 \mathrm{~cm}$ & $0 \%$ \\
$\mathrm{SC} \mathrm{02}$ & $\mathrm{N} 45^{\circ} 58.489^{\prime} \mathrm{W} 64^{\circ} 43.833^{\prime}$ & $1 \mathrm{~m}$ & $10 \mathrm{~cm}$ & $50-75 \%$ \\
$\mathrm{SC} 03$ & $\mathrm{~N} 45^{\circ} 58.515^{\prime} \mathrm{W} 64^{\circ} 44.043^{\prime}$ & $3 \mathrm{~m}$ & $15 \mathrm{~cm}$ & $75-100 \%$ \\
$\mathrm{SC} 04$ & $\mathrm{~N} 45^{\circ} 57.549^{\prime} \mathrm{W} 64^{\circ} 44.476^{\prime}$ & $1 \mathrm{~m}$ & $11 \mathrm{~cm}$ & $75-100 \%$ \\
$\mathrm{SC} 05$ & $\mathrm{~N} 45^{\circ} 58.448^{\prime} \mathrm{W} 64^{\circ} 44.631^{\prime}$ & $2 \mathrm{~m}$ & $15 \mathrm{~cm}$ & $75-100 \%$ \\
\hline
\end{tabular}




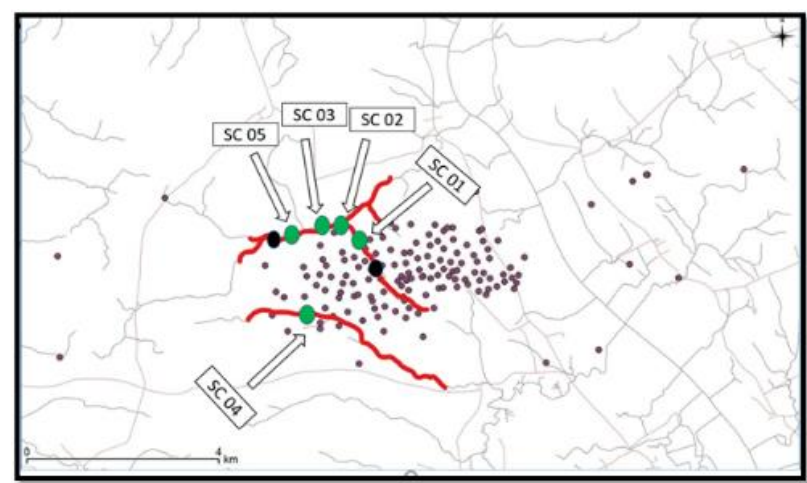

Figure 2. Map of selected seepage sites in Stoney Creek stream (green dots) including abandoned oil well sites in smaller purple dots. Black dots are identified thermal sites that were not selected. Red line indicates area within the Stoney Creek streams assessed utilizing the stream walk technique. Base layout from GeoNB using QGIS software.

Biofilm was collected at each site by scraping rocks which were selected randomly upstream and downstream from the suspected groundwater input. Microorganism scraped from solids surfaces indicating were not quantified or identified. The composite sample was subdivided for two different analyses; stable isotope analysis and algae species identification. Samples were preserved in $95 \%$ ethanol for stable isotope analysis, while samples for algal identification were preserved in a 1:1 ratio of $10 \%$ buffered formalin and distilled water. Algae samples were shipped to the Institut National de la Recherche Scientifique (INRS) in Quebec City in rounded $100 \mathrm{~mL}$ leak-proof sample specimen containers. Benthic macroinvertebrates were collected by traversing the sample area with a kick net in a zig-zag pattern, moving from bank to bank and working in a upstream direction for approximately a 3-5 minutes. Macroinvertebrates were selected based on availability and abundance throughout all sites.

\section{Stable isotope laboratory analysis}

Macroinvertebrates were identified to family levels and classified into different feeding groups following Merritt and Cummins (2008) (Table 1). Biofilm and macroinvertebrates from each site were dried at $60^{\circ} \mathrm{C}$ for 24 hours. After the biofilm were dried, they were scraped from the petri dishes into a sealed Eppendorf tube. Large macroinvertebrates were homogenized using a mortar and pestle while smaller macroinvertebrates were exempted, since tissue sample could be loss from the grinding. Each individual macroinvertebrate and biofilm were held in its own Eppendorf tubes before submission at the Stable Isotopes in Nature Laboratory (SINLAB), UNB, Fredericton.

At the Stable isotope lab, macroinvertebrates samples were weighed at between $0.5-1 \mathrm{mg}$ while biofilms samples were weighed at approximately $3 \mathrm{mg}$ into small tin cups for $\delta{ }^{13} \mathrm{C}$ and $\delta{ }^{15} \mathrm{~N}$ analysis. After all samples had been measured, they were combusted and analyzed in a Finnigan Mat Delta Plus continuous-flow, isotope-ratio mass spectrometer (Thermo Fisher Scientific, Waltham, Massachusetts) connected to a ThermoQuest NC2500 elemental analyzer (Thermo Fisher Scientific).

\section{Diatom assessment (INRS) of Stoney Creek sites}

Biofilm samples received by INRS lab personnel were placed in nitric acid for 48 hours, and then hydrogen peroxide $30 \%$ was added to samples for another 48 hours. This removed all traces of organic matter within the samples, thereby isolating the diatom frustcles. At the end of the digestion period, samples were rinsed repeatedly to remove any remaining nitric acid. Microscope slides were prepared for cleaned diatom observation using Naphrax (®) as the mounting medium (refractive index: 1.74; Brunel microscopes Ltd). Diatom assemblages were observed under a Reichert-Jung Polyvar microscope equipped with differential interference contrast (magnification 1250x). Several hundred diatom valves were identified on each slide and diatom assemblages were expressed as relative abundances of the species assemblage. Taxonomic identification mainly followed (Lavoie et al. 2008). IDEC scores (Eastern Canadian Diatom Index; Lavoie et al. 2006, 2014) were determined for each diatom assemblage while referencing IDEC-mineral, which is the recommended sub-index to use (Grenier et al. 2006) based on the characteristics of the studied watersheds (geology, surficial deposits). IDEC scores were valued between 0 and 100, with low values indicating poor biological integrity.

\section{Statistical Data Analysis}

The R software program was used to conduct various statistical analyses. All sites were geographically close with minimal deviation in physical characteristics among sites, so a simple paired t-test was used to assess the differences upstream and downstream across sites. The paired t-test compared stable isotope values of benthic macroinvertebrates and biofilm between upstream and downstream groundwater input source. In a more complex situation with diatom assemblages with several different taxa and different abundances, with upstream and downstream a multivariate analysis was done. Permutational multivariate analysis of variance (PERMANOVA), compared the difference among all site with a factor level added comparing diatoms upstream to downstream. The permutation was done 999 times on vegan software package on R.

\section{Results}

\section{Physical characteristics sites}

With the use of the thermal camera, I identified five sites with groundwater input. The iPad mini connected to the Seek thermal camera showed temperature changes at the base of the groundwater water source. The thermal camera indicated downstream the ground water source averaged $4^{\circ} \mathrm{C}$ cooler in contrast to upstream site across all sites. At the entrance of the groundwater the temperature was significantly lowered downstream in all sites but increased downstream away from groundwater base (Figure 3). The precise YSI Promodel 2030 measured water temperature at $1.38 \pm 0.146$ (mean difference $\pm \mathrm{SD}$ ) degrees lower 10 meters downstream of observed groundwater seepage points (paired t-test, $\mathrm{n}=5 ; \mathrm{df}=4, \mathrm{t}=-$ 2.0962, $\mathrm{P}=0.1041$; site values presented in table 2 ). $\mathrm{P}$ value indicated there was no statistical temperature difference 10 meters upstream and downstream the seepage source where samples were collected. Mean $\mathrm{pH}$ value was slightly more acidic downstream $0.33 \pm 0.105$ (paired t-test, $\mathrm{n}=5$; $\mathrm{df}=4, \mathrm{t}=$ 
$-2.7826, \mathrm{P}=0.049$; site values presented in table 2 ). $\mathrm{P}$ value indicated that there was a statistical difference in $\mathrm{pH}$ values 10 meters upstream to downstream the seepage point.

Interestingly, two sites had signs of acid mine drainage (AMD) originating at the base of groundwater source. Site SC 03 (Figure 4A) had $\mathrm{pH}$ level 7.26 at the base of the groundwater source in comparison to upstream 7.73 and downstream 7.78 (measured $\mathrm{pH}$ level not shown in Table 2). The second site with visible acid mine drainage was not measured see (Figure 4B). Site SC 02 had an AMD located approximately 300 meters upstream of the groundwater source ( $\mathrm{pH}$ not measured).

Initially, I aimed to sample Fish (minnows and sculpin), benthic macroinvertebrates and biofilm local to the stream. However, due to and low water levels the abundance of fish was low. Fish sampling was ineffective, resulting in a total of two brook trout (BK1: 95mm fork length, 7.80g; BK2: $88 \mathrm{~mm}$ fork length, $6.46 \mathrm{~g}$ ) captured using baited minnow traps. Both individuals were sampled (fin clip) from SC 04 DS and released but the low sample size precluded any subsequent statistical analyses.
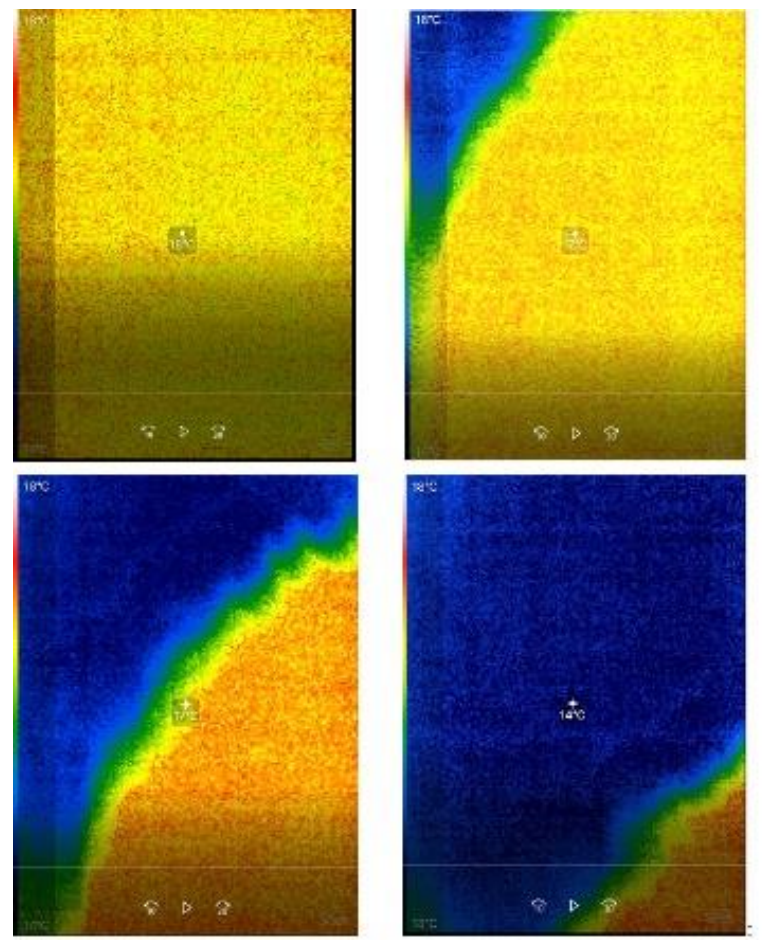

Figure 3. Seek thermal camera images shows the transition of normal stream water temperature to the ground water source in Stoney Creek stream site SC 04. (A->D) indicates drastic temperature changes as the thermal camera hovered from the warmer stream temperature to the base of groundwater source.

Table 2. Multiple stream parameters measured using YSI Promodel 2030 at various environmental conditions. US signifies Upstream groundwater seepage source and DS signifies downstream seepage source. $\mathrm{X}$ indicates sites with invisible groundwater seepage into the stream.
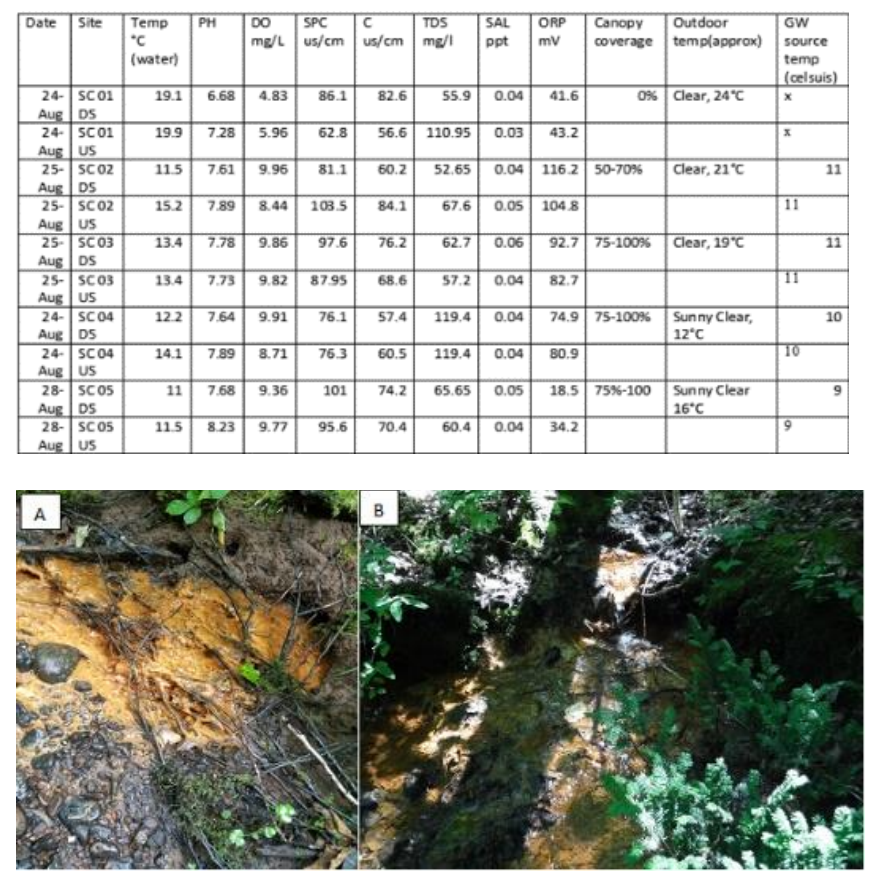

Figure 4. Photographs of sites SC 03(A) and SC 05(B)displaying signs of acid mine drainage originating from the base of groundwater source.

\section{Stable isotope analysis (Biofilm results)}

Nitrogen values of biofilm samples were lower compared to benthic invertebrate's samples. Carbon isotope values ranged between $-34 \%$ to $-29 \%$ upstream and downstream across all test sites (Figure 6 and 7). Mean values for upstream sites was calculated to be $-30.7 \%$ downstream and a slight increase upstream $-30.6 \%$. Paired t-test: $\mathrm{t}=0.15624, \mathrm{df}=4$, $\mathrm{p}$ value $=0.8834$. Also, slight difference in nitrogen isotopic value with change as $3.2 \%$ for downstream and $2.7 \%$ for upstream values. Paired t-test: $\mathrm{t}=-1.1524, \mathrm{df}=4, \mathrm{p}$-value $=$ 0.3133. No statistical significance was found between upstream to downstream ground water source with biofilm values.

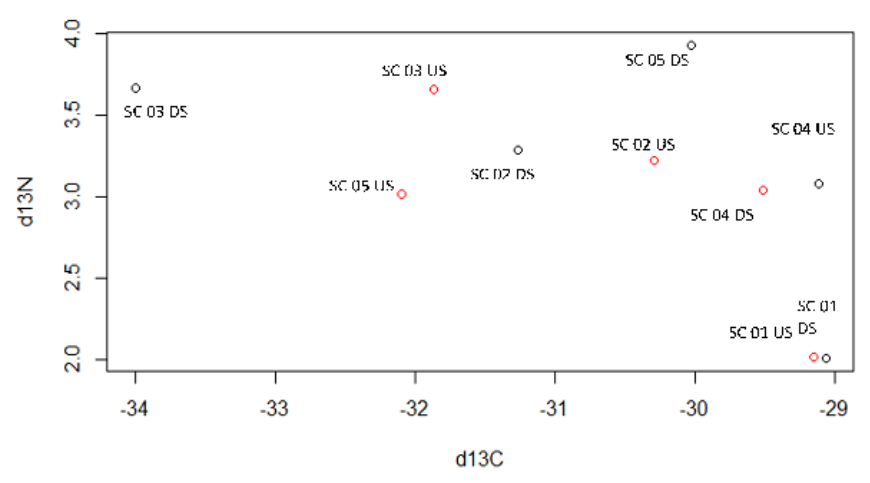


Figure 5: Scatter plot of carbon isotope values on the horizontal axis in relation to Nitrogen isotopic value on the vertical axis. Upstream is colored red downstream is colored black.
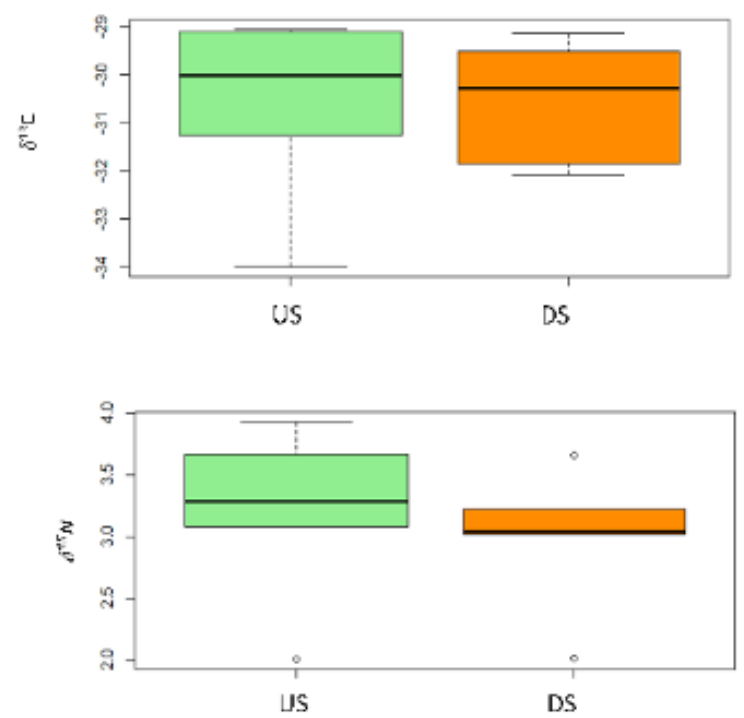

Figure 6. Boxplot indicates range of biofilm $\delta^{13} \mathrm{C}$ values (top) and $\delta^{15} \mathrm{~N}$ values (bottom) compared downstream (DS) to upstream (US) across all sites.

\section{Stable isotope analysis (Benthic Macroinvertebrates)}

The kick net zigzag technique was successful with diverse family groups captured from various sites. Benthic invertebrates caught from target sites were classified into respective functional feeding group and family taxa (Merritt and Cummins 2008). Among the macroinvertebrates, predators dominated most of the samples (24 individual samples), then followed by collectors/filterer (15 samples), then collectors/ gatherer (5 samples), and shredders at lowest abundance in sampled data (4 samples). Carbon stable isotope values were averaged within each classification and a mean value for US and DS in each functional feeding group was calculated. Paired test between individual values could not be done by itself due to unequal number of family sampled from each site, so mean $\delta^{13} \mathrm{C}$ values of US and DS sites were taken for all feeding groups compared among sites. $\delta^{13} \mathrm{C}$ values for combined functional feeding group sampled resulted in a mean difference $(-1.4 \pm 0.05)$ upstream to downstream and statistical analysis (paired t-test, $\mathrm{n}=4 ; \mathrm{t}=6.489, \mathrm{df}=3, \mathrm{p}=0.00743$ ) suggested that downstream was more depleted in $\delta^{13} \mathrm{C}$ than upstream groups. $\delta{ }^{15} \mathrm{~N}$ for combined functional feeding groups (mean difference $0.16 \pm 0.23$ ) was not significant upstream to downstream (paired t-test, $\mathrm{n}=4 ; \mathrm{t}=0.49959, \mathrm{df}=3, \mathrm{p}=0.6517$ ) (Figure 7).
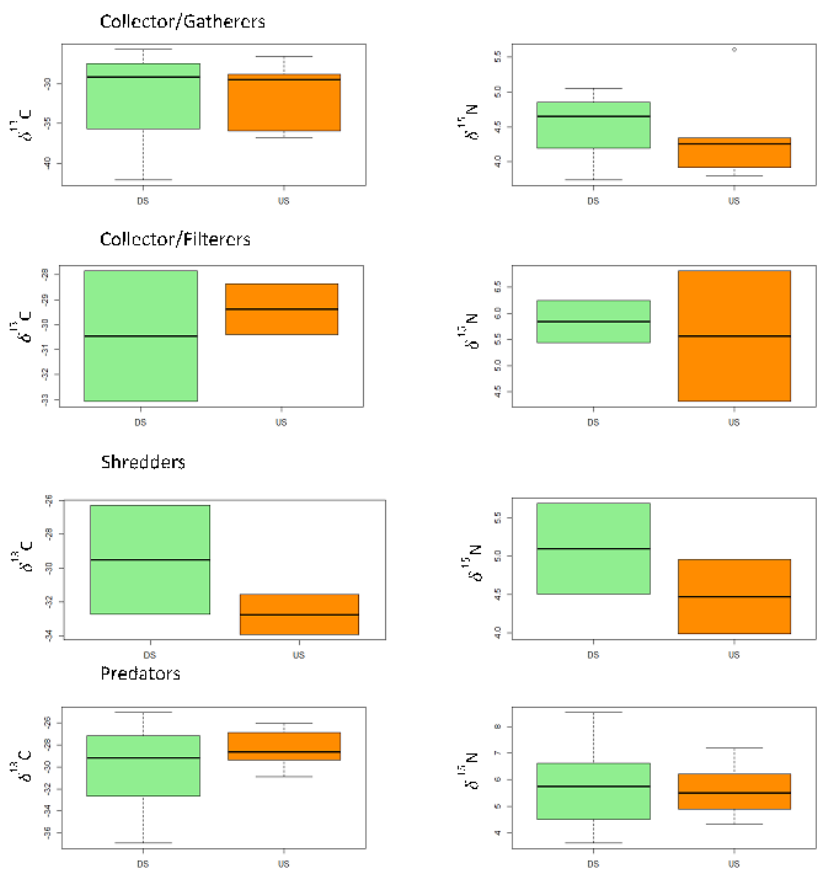

Figure 7. boxplot for $\delta^{13} \mathrm{C}$ (left) and $\delta{ }^{15} \mathrm{~N}$ (right) functional feeding groups datasets (47 samples total). US represents upstream of groundwater source and DS represents downstream of groundwater source. (Merritt and Cummins 2008).

Across each site, mean value and standard deviation were also reported in a bi-plot for upstream value and downstream values (Figure 8). Variability from stable isotope biplots (Figure 8) is visible especially in downstream seepage sites compared to upstream across all sites. Figure 9 displays each individual ${ }^{13} \mathrm{C}$ isotopic value sampled by sites upstream to downstream of groundwater source. Mean value for each site was used in a paired t-test analysis to examine if there were differences between macroinvertebrates upstream and downstream in each site. $\delta^{13} \mathrm{C}$ downstream was slightly depleted $(1.2 \pm 1.8)$ than upstream (paired t-test; $\mathrm{n}=5, \mathrm{t}=$ 0.99191 , df $=4, p-=0.3774$ ) but not statistically significant. There was no difference in $\delta^{15} \mathrm{~N}$ upstream to downstream with mean difference $(0.2 \pm 0.08)$ (paired t-test: $\mathrm{n}=5, \mathrm{t}=-0.76559$, $\mathrm{df}$ $=4, \mathrm{p}=0.4866$ ).

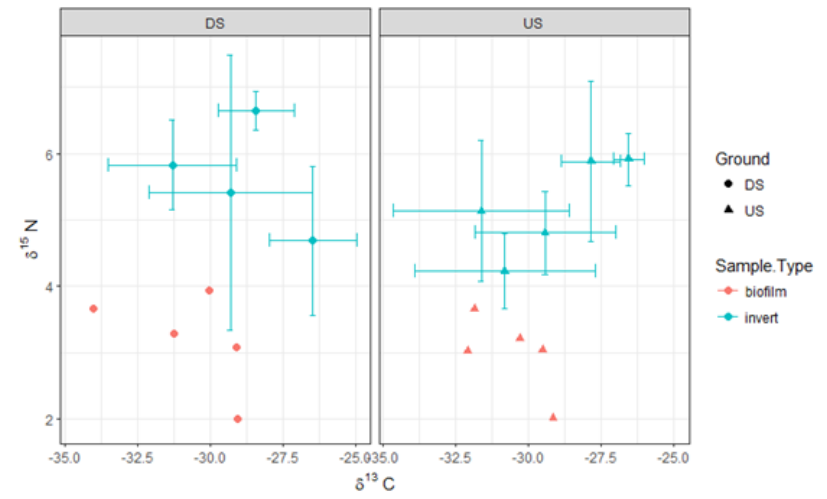


Figure 8. Stable isotope Biplots of carbon to nitrogen marker of a sampled data (biofilm and benthic invertebrates) across all sites. Each dot represents the mean value of the sample at a site and sites with multiple samples included standard deviation.

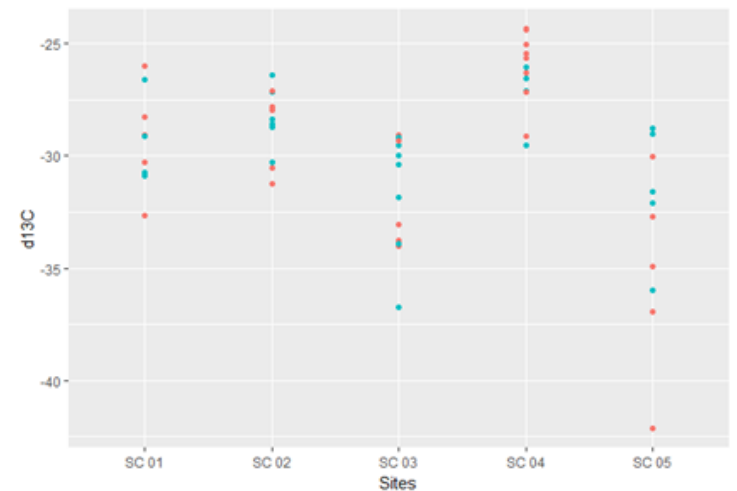

Figure 9. $\delta^{13} \mathrm{C}$ value depletion across sites sampled upstream and downstream groundwater source in Stoney Creek. $\delta^{13} \mathrm{C}$ value includes both biofilm and benthic invertebrates' samples across all sites.

\section{Diatom assessment results}

Each site was assessed based on the presence and abundance of diatom taxa in comparison to upstream and downstream from a groundwater source. After microscopic analysis, I found similar diatom taxa dominating between upstream and downstream across each site (Figure 10). However, the relative abundance was different between upstream and downstream. The bar graph below shows the relative abundance of the prevalent diatom taxa in each site with 'others' indicating combination of the less prevalent taxa. No consistent pattern were visible between across all sites; for example, ADMI (Achnanthidium minutissimum var. minutissimum Complex) One of the more dominant taxa, was more abundant upstream in some sites but reduced drastically downstream of the target site SC 05 (Figure 10A, 10B,10C,10E). In site SC 01 and SC 04 EUNO (Eunotia spp.), dominated upstream of groundwater source but abundance reduced drastically downstream (Figure 10A and D). At all sites, GTSM (Gomphonema stoermeri) and NVCC (Navicula viridulacalcis) diminished in relative abundance upstream to downstream in each site, where they were present. Interestingly, DMES (Diatoma mesodon) was present downstream; however, it was not upstream of the groundwater source (Figure D). A permutational multivariate analysis of variance (PERMANOVA) test was done on raw values from enumerated diatom taxa to test the variability among each site and found there were no differences detected in taxa across sites $(\mathrm{p}=0.141)$, or upstream versus downstream $(\mathrm{p}=0.832)$.

The study sites fall under the classification of IDEC mineralized sub index based on its geological location (Table 3) (Grenier et al. 2006). IDEC scores were assigned to individual sites using IDEC mineralized based on the geographical location of the sites. Across all test sites, the diatom assemblages displayed values that were slightly polluted in comparison to the references sites. Upstream to downstream of groundwater source were both 'slightly polluted' with a small IDEC score difference of $( \pm) 4.2$ across all sites (Table 4). These sites ranged between 69 and 46 (Table 4), which fell in the somewhat polluted range (45-75) from (Lavoie et al. 2014).
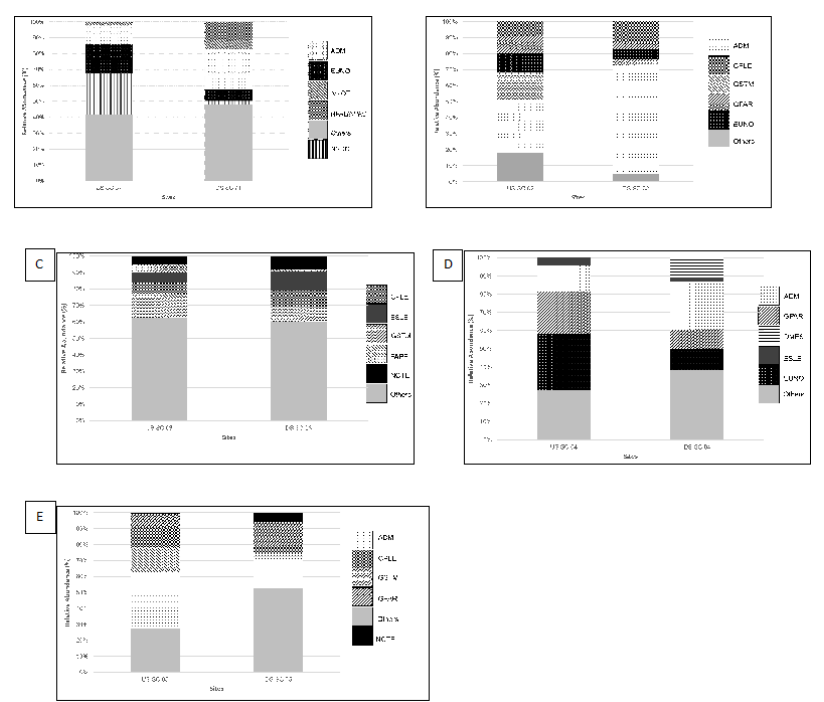

Figure 10. Diatom taxa relative abundance upstream (US) compared to downstream(DS) of sampled groundwater source.

Table 3. Biological integrity class given to different subindexes and their corresponding range. Table from (Lavoie et al. 2014)

\begin{tabular}{llll}
\hline $\begin{array}{l}\text { Biological integity } \\
\text { classes }\end{array}$ & Range in DEC values & & \\
\hline A & DEC-Neutral & DEC- Alkaline & DEC- Mineralized \\
B & $70-100$ & $70-100$ & $75-100$ \\
C & $45-70$ & $45-70$ & $45-75$ \\
D & $20-45$ & $25-45$ & $25-45$ \\
\hline
\end{tabular}

Table 4. IDEC scores given to groundwater seepage sites found in Stoney Creek and biological integrity classified based on IDEC-Mineralized ranges compared with (Lavoie et al. 2014).

\begin{tabular}{l|l|l} 
Sites & IDEC scores & $\begin{array}{l}\text { Biological } \\
\text { integrity }\end{array}$ \\
\hline US SC 01 & 65 & B \\
\hline DS SC 01 & 69 & B \\
\hline US SC 02 & 64 & B \\
\hline DS SC 02 & 47 & B \\
US SC 03 & 66 & B \\
\hline DS SC 03 & 64 & B \\
\hline US SC 04 & 48 & B \\
\hline DS SC 04 & 46 & B \\
\hline US SC 05 & 56 & B \\
\hline DS SC 05 & 60 & \\
\hline
\end{tabular}




\section{Discussion}

\section{Thermal imagery}

The use of a thermal imagery to detect groundwater flux into streams is not new. Groundwater naturally flows from underground aquifers into streams which adds to streams, wetlands and rivers water budget and helps to maintain stream levels in the dry season (Duarte et al. 2006). Groundwater is protected from the radiation from the sun or surroundings, so groundwater temperature seeping through stays cool throughout the summer season. Several studies have used more sophisticated means of identifying seepage on a larger scale, both spatially and temporally, such as aerial studies (Duarte et al. 2006, Johnson et al. 2008), and ground temperature probes (Lowry, et.al 2007), etc. The novel stream walk technique with a hand-held device used for this study is cost efficient but is also labor intensive. The method can only be utilized at a particular time of the day since environmental conditions can easily affect the temperature of the stream. This technique restricts a person to a certain time of the day where is it not too hot or too cold. The hand held SEEK thermal device works for this study because there are no other factors added to the sites apart from detecting temperature differences between stream temperature and groundwater source. This was successful in terms of completing the assigned task since both hand-held devices were used in discovering 7 sites (narrowed down to 5 sites). As successful and cost efficient as the method may be, essential factors such as quantifying the groundwater inflow could not be assessed. Researchers are still trying to determine effective ways to quantify groundwater seepage (Schuetz et al. 2011). For my study, measuring the groundwater seepage can also lead to better assessment of the seepage of methane. This could have implications for stable isotope analysis or diatom assessment as large quantities of methane seepage causes a more drastic change downstream of groundwater source in comparison to lower methane seepage. This means that high methane seepage through high flux of groundwater input can be detected easily compared to low groundwater seepage and low methane input. However, this technique does not guarantee the detection of methane contamination in the groundwater source, it requires additional analysis to confirm whether the seepage could represent a potential methane input.

\section{Stable isotopes}

The first step in the stable isotope analysis of the Stony Creek stream was to develop a flexible value that exhibits the presence of methane. I set a value of $\simeq-45 \%$ or $\delta 13 \mathrm{C}$ for identifying the presence of methane uptake into the food web from a literature (Whiticar 1999). Nevertheless, it is still important to know that environmental factors such as temperature or physio-chemistry of stream water within several sites is bound to influence the stable isotope ratio (Håkansson 1985), and different ecosystems having different environmental factors affecting $\delta 15 \mathrm{~N}$ or $\delta 13 \mathrm{C}$ fractionation (Post 2002).

Stream biofilm samples are extremely diverse across spatial scale, and depending on their favored resource bioavailability, algae, cyanobacteria, bacteria, can all form biofilm (Battin et al. 2016). Autotrophic cyanobacteria and various algae native to various headwater streams are able to utilize the sunlight and undergo the photosynthetic process and If conditions are right most bacteria will reproduce rapidly
(Battin et al. 2016). Fractionation occurs during this physiological process where carbon isotopic values generally ranges from $-11 \%$ to $-39 \%$ for algae and photosynthetic bacteria (Farquhar et al. 1983). Stoney Creek region with leaky abandoned oil well mines could potentially have methane seeping into the streams creating another food source for the streams. Similarly, to a rice paddies field, wetland, or enteric system where methane is abundant, methanotrophs will grow and bacteria multiplication is favored (Dubey 2005). Methane creates a desirable condition for methanotrophs, so methane seeping into the Stoney Creek streams should increase the abundance of methanotrophs downstream of groundwater source. Methanotrophs are significantly distinct with carbon isotopic values $(<-45 \%$ ). With segregation between different classes of microorganisms, it is possible to construct a clearer stable isotope energy flow $\delta^{15} \mathrm{~N}$ to $\delta{ }^{13} \mathrm{C}$ biplots relating consumers and prey (Fry 2006) especially in situations where it is hypothesized that methanotrophs (methane oxiding bacteria) abundance downstream to the site will shift the carbon isotopic value of the sites. Although Methanotrophs were not specifically identified from the biofilm samples, stable isotope results should still show a significant ${ }^{13} \mathrm{C}$ depletion or variation downstream in comparison to upstream if present (Whiticar 1999). However, the results (biofilm average value was $-30 \%$ US and DS) indicated that methanotrophs were not present or abundant in comparison to their photoautotrophic counterparts across all sites. My samples did not display a significant change downstream of the sample source for biofilm values which suggest that a) methane's presence might be too low to detect or b) methane oxidizers are absent in Stoney Creek aquatic ecosystem.

Difficulty in confirming the presence of methane oxidizing bacteria in the lower (biofilm) level will affect the next trophic level (i.e. benthic macroinvertebrates). This is evident with the results from the mass spectrometry where results ranged from $-24 \%$ o to $-42 \%$ with only one extreme outlier of $-42 \%$ (Figure 12). Across all sites (US and DS), macroinvertebrates mean values was approximately -30\%o (Figure 12) which was quite usual to consumer feeding on primary allochthonous sources $(-28 \%$ to $-26 \%$ or autochthonous aquatic algae assimilated by macroinvertebrates $(-35 \%$ to $-25 \%$ ) (Grey et al. 2000, Peterson and Fry 1987). High standard deviation and high variability in Figure 12 for biofilm samples can be attributed to low sample size collected from individual sites. Interestingly, only one macroinvertebrate in site SC 05 measured was usually ${ }^{13} \mathrm{C}$ depleted; however, upon closer inspection the mass sampled was $0.005 \mathrm{mg}$. The typical weight measurement was between $1.0-1.5 \mathrm{mg}$ for macroinvertebrates but this small sample weight was still analyzed under extremely low weight. Despite the fact that stable isotope mass spectrometry is very precise under low weight (Jardine et al. 2003), the mass sample might be too low to generate an accurate drop since there is a higher risk for contamination from handling leading to changes in isotopic ratio in the Chironomidae sample (Ben-David and Flaherty 2012). The unusual Chironomidae sample from the site, in addition to low sample size resulted in high variability specifically at site SC 05 (Figure 11).

However, I cannot ignore some studies which have identified Chironomidae family as the main gateway to methane derived carbon. These organisms have been discovered to transfer methane carbon into the food web from 
studies. For instance, Stictochironomus sp., a Chironomidae found in Lake Biwa, Japan averaged -45\% (Kiyashko et al. 2001) and another Chironomidae found in Loch Ness, Scotland averaged $\simeq-40 \%$ ( Jone \& Grey 2011). My sample $\delta^{13} \mathrm{C}$ value is suspiciously close in range to those isotopic values from those studies but I cannot generate a conclusion from a single sample. Also, samples from site SC 05 seem to be depleted (Figure 12) in contrast to other sites. Further investigation would be needed on site SC 05 to better determine if methane is a factor or stable isotope mass spectrometer is detecting a false positive result due to the weight.

Macroinvertebrate families caught from the zigzag kick sampling technique differed between each site and were different upstream to downstream. To generate a strong supporting evidence of methane presence in the aquatic environment it is essential to have invertebrates from the same family present upstream and downstream the target site. However, from the study results, most sites had different family taxa and different functional feeding groups. Interestingly, out of the 5 classifications of benthic invertebrates, only 4 different functional feeding groups were found in my samples. Majority of my sample data were predators (30 out of 47 samples), which fed on other invertebrates, then followed by, gatherers/collectors which consume fine particulate organic matter as a source of carbon (Wallace and Webster 1996). The two smaller functional feeding groups were shredders, which typically feed on decomposing plant tissue, and decomposing allochthonous wood, while collector/filterers have specialized structure allowing filtering and collection of organic substrate at bottom sediments. The only family absent in the sample were scrapers, which graze organic materials from periphyton and attached algae. Due to invertebrates' feeding strategies and its behaviormorphological mechanisms, their feeding pattern is predictable (Merritt and Cummins 2008). The smaller sub population (gatherers/collectors, filterers, and shredder) which were collected from each site fed primarily on detritus allochthonous leaf litters and decaying organisms but not usually microorganisms (Wallace and Webster 1996). The absolute mean was similar for both upstream and downstream and also fell within consumers allochthonous leaf litter or decomposing organism ( $-28 \%$ oto $-26 \%$; Peterson and Fry 1987). The appearance of grazers in my samples may have been useful in identifying the presence of methanotrophs or microorganisms needed to detect methane since biofilm contributed to a large amount of their diet (Mcneeey et al. 2007). Grazers minimal presence in my sampling results could also be attributed to (Vanote et al. 1980)'s river continuum concept, which suggest that area with more shaded canopy coverage gets less algae instream production, which affects the population of grazers and increases terrestrial detritus as a major source entering the stream in headwater stream.

Macroinvertebrate role is crucial in the food web as it serves as an energy conduit in the process of energy transfer in the lotic freshwater food web (Wallace and Webster 1996). Effects or changes are propagated easily and can be visualized through organisms from these trophic levels. Due to diverse feeding strategies and feeding source, they can act to incorporate various biomasses from different energy sources. This trophic level is essential in carbon isotope analysis because samples are more specific to their carbon source at this level. The relationship between the carbon source is more apparent compared to a fish with more diluted carbon source. For example, a grazer feeding primarily on algae in a stream ecosystem will have direct isotopic signature similar to the algae; however, a fish feeding on several different families of macroinvertebrates will have a more convoluted $\delta^{13} \mathrm{C}$ value. Nevertheless, Fish samples are still useful in reinforcing feeding relationships with a linear correlation with the lower level.

${ }^{13} \mathrm{C}$ isotope is mainly used to identify the presence of methane (Whiticar 1999); nevertheless, ${ }^{15} \mathrm{~N}$ isotope is still essential in my study. Trophic enrichment is minimal in $\delta^{13} \mathrm{C}$; however, $\delta^{15} \mathrm{~N}$ enrichment is accepted as 3-4\%o the higher the organism is on the food chain (Peterson and Fry 1987, Fry 2006). This is an advantage because nitrogen isotope can confirm and guarantee each trophic level sampled. The combination of carbon and nitrogen isotope ratios is a powerful ecological tool that can be used to analyze complex food web systems (Fry 2006). In cases where methane is present, there is another task of comparing whether my results are due to differences in thermogenic methane (derived from breakdown of larger organic molecules) or biogenic methane (methanogenesis from microbial organism). Carbon fractionation between the distinct sources are weak, since an overlap between the sources is possible (Whiticar1999). The addition of another isotopic marker such as hydrogen is essential in distinguishing between the sources. Hydrogen fractionation is more enriched in thermogenic methane $-150 \%$ o in comparison to biogenic methane with $-350 \%$ (Whiticar 1999, Stopler et al. 2015). Methane oxidizing bacteria have been found to fractionate carbon or hydrogen isotopes, depending on the source (Coleman 1981). The addition of hydrogen isotope would increase the power to my analysis.

\section{Diatoms assessment}

Diatom assessment and biomonitoring is one of the promising tools in evaluating aquatic stream health (Lavoie et.al 2006). This method for this study was used to examine if the presence of methane in the aquatic ecosystem would cause changes in the lowest trophic level. Diatoms are very sensitive to environmental change. Introduction of foreign compounds could act as a pollutant causing slight changes in diatom taxa abundance. Even the slightest physical site change will affect diatom results (Lavoie et.al 2006). Upon investigation of methane seepage into the Stoney Creek aquatic stream, my study sites indicated that most of the sites did not have a significant change in diatom taxa from upstream to downstream (Figure 13-17). Multivariate analyses suggested that there was no significant change in overall diatom abundance across sites or between upstream and downstream within a site. Since there was no directional pattern I can be attribute discrepancies in diatom abundance visible per site to several factors (e.g., location, growth factors) which have not been in assessed in this study.

A diatom-based index was used on diatom assemblages relative abundance to determine how polluted the sites were. The index value ranges from 0 to 100 measuring the deviation between reference sites and impacted site with 100 as the reference condition. One of the advantages of this method of assessment is the incorporation of several environmental variabilities and it compares it to a pristine nonpolluted reference site. The latest IDEC 3.0 includes a new sub index which classifies reference sites to IDEC mineralized, IDEC 
neutral, and IDEC alkaline based on accumulation of several pristine study sites (Lavoie et al. 2014). Stoney Creek is in the Southwestern region in eastern Canada, which means it will have a distinct physio-geographical characteristic. I used an IDEC mineralized for the reference location and I assigned values in my sites which fell within the range of 69 to 46. However, due to the \pm 2 error associated with IDEC scoring system, some of these values might be falling below polluted zone (Lavoie et al. 2014). These sites include US SC 04, DS SC 04 and DS SC 02 (Table 4).

Although all sites were generally similar scores, Site SC 02 displayed divergent IDEC scores between upstream (64) and downstream (47) of the groundwater seeps. Methane could be a potential factor causing this pollution in the streams, however, these changes are not consistent throughout the site. With my prediction, downstream should be more polluted compared to upstream consistently across all sites. Other factors could also have impacted the streams such as acid mine drainage, which was located at several spots (not shown in result section) flowing directly into the stream at the base of groundwater seepage. I might be able to attribute these changes to acid mine drainage, which was located approximately $500 \mathrm{~m}$ upstream to site SC 02, while SC 03 and SC 05 had acid mine drainage at the base of the ground water source. Acid mine drainage might be a factor contributing to pollution because IDEC is sensitive to natural or anthropogenic acidification (Lavoie et al. 2014). However, sites with obvious Acid mine drainage did not show any difference in IDEC scores compared to other sites without this factor. "Slight pollution" could be the result of an unknown factor unaccounted for in the study. This is one of the disadvantages for this assessment tool because it requires additional information to determine what is causing the change. The biomonitoring tool could only conclude that a change is currently occurring in a certain area but could not identify the source of the change.

\section{Effectiveness of tools used in the study to detect methane}

This study combines several tools in order to investigate the presence of methane among my study sites. It serves as an exploration and application of tools and techniques that have not previously been applied in this context. Firstly, a thermal imaging camera was used to identity cold water seeps with potential methane contamination. Secondly, stable isotope analysis was used to determine if there was methane uptake in the system, and thirdly, diatom assessment was used to see the impact of methane and to further reinforce the result. Each technique has its own weakness and strength, however, merging these methods could compensate for the deficiencies of each analysis.

The stable isotope results did not indicate any signs of methane occurrence or uptake and low IDEC scores could be attributed to some other factors in the stream. It could be the case that methane is not significantly impacting the system since most of my thermal spots were trickling into the streams in small amounts. While scanning most of the Stoney Creek stream system with the thermal camera ( $20 \mathrm{~km}$ area), only 7 ground water sources (narrowed to 5 thermal spots) were found, and further visual inspection also showed low input of groundwater seepage. The volume of the seepage was not measured but most sites had groundwater trickled slowly into the streams. If methane was seeping through in extremely low quantities from the seepage site, the impact could be restricted only to the entrance of the groundwater source. For this study, approximately 10 meters upstream and downstream were sampled away from the groundwater source. It would be intriguing to see if there are changes spatially with sample collection starting from the base of groundwater source. Potentially, there could be possible impacts with the stronger effects directly at the source but deteriorates as it transitions away from the source (upstream/ downstream). IDEC scores with 2-3-meter intervals would also support this method with a positive relationship indicating significant changes in the scores as movement occurs away from the sites. Stable isotope analysis would need a greater separation with spatial interval around 15-20 meters from ground water source due to benthic invertebrate's mobility, so greater intervals would account for its movement over its lifetime.

This study only accounted for the 5 test sites that were sampled with the variable examining effects downstream or upstream of seepage site. Although the sites were geographically related, there were slight physiological stream differences between sites. For example, dissolved oxygen of site $\mathrm{SC} 01$ averaged $5.3 \mathrm{mg} / \mathrm{l}$ compared to the rest of the sites which averaged over $9 \mathrm{mg} / \mathrm{l}$. The implication of these differences is that I do not know if my physical site characteristics are affecting the outcome of the study. Also, sampling upstream of seepage site might not be useful because downstream of a seepage hypothetical "site A" could affect upstream hypothetical "site B" if both sites are located on the same stream continuum. An inclusion of a reference site is essential to increase my reliability for the results. It also helps to eliminate the confounding variable in the environment that could affect the outcome so that test sites can be compared. A reference site for this study could be a stream in the same watershed or river system geographically close to the Stoney Creek river without any anthropogenic impact.

For stable isotope analysis, I did not have sufficient data for my fish samples as originally intended, so I settled for benthic invertebrates and biofilm samples. The values for the samples I received were in the $-26 \%$ range, suggesting they could be feeding on expected local domestic values rather than foreign methane input. Even if I Increased the fish sample I might not attain isotopic value similar to $-45 \%$, and it would be more diluted as the trophic level increased (Ben-David and Flaherty 2012). Most fishes native to stream are generalist, meaning they consume multiple other carbon sources for energy and with their increased mobility, methane traces would be harder to resolve from their tissue samples. Although it would be interesting to see 3 or more trophic levels in the stable isotope analysis, it would also be adequate to have just the biofilm values and benthic macroinvertebrates in the investigation of methane.

My study concentrated on sampling biotic parameters from different trophic levels to investigate the presence of methane, however, this study assumes methane seepage is already present in the streams. Previous studies have used stable isotopes to examine contamination of methane by directly sampling from water source (Osborn et al. 2011). $\delta^{2} \mathrm{H}$ and $\delta{ }^{13} \mathrm{C}$ were coupled together in detecting thermogenic methane concentration in drinking water. Likewise, I could sample ground water seepage directly to confirm the presence of methane first, before sampling the biotic parameters. So, any unusual changes found in the streams using the protocol could be attributed to methane contamination. 
The combination of SEEK thermal temperature sensing technology, stable isotope for detection of methane uptake into the food web, and diatoms were could be used to detect methane and its impact in the food web. Despite not finding methane in Stoney Creek sites, there are still some research questions that could be explored before ruling this application out as a tool to find and detect methane emissions in the aquatic environment. It would be interesting to see a reference site added to the study, combined with a higher trophic level (fish level) and the inclusion of a marker such as hydrogen isotope to help confirm the presence of methane. Further research would involve analyses of sites with already confirmed methane contamination to test the reliability or the effectiveness of these tools. The combination of these inexpensive tools could be integral in developing methods in the near future that could help detect methane in the aquatic ecosystem efficiently.

\section{Acknowledgments}

This work was funded by Natural Resources Canada (NRCan) Clean Energy Innovation Fund under the Gas Seepage Project (GaSP) "Assessing methane emissions from legacy fossil resource development and methane mitigation potential in Atlantic Canada", led by the principal investigator Dr. Grant Wach of Dalhousie University. My fieldwork was assisted by Tyler Golding and Zach Bourque, as well as my supervisor Dr. Michelle Gray and Dr. Brian Hayden. I wish to thank Kristie Heard and Brianna Levenstein for tips and advice on macroinvertebrates identification and Isabelle Lavoie for helping with diatom assessment.

\section{References}

Antoniades, D., \& Douglas, M. S. V. (2002). Characterization of high arctic stream diatom assemblages from Cornwallis Island, Nunavut, Canada. Can. J Bot, 80, 50-58. https://doi.org/10.1139/B01-133

Bachu, S. (2017). Analysis of gas leakage occurrence along wells in Alberta, Canada, from a GHG perspective Gas migration outside well casing. International Journal of Greenhouse Gas Control, 61, 146-154. https://doi.org/10.1016/j.ijggc.2017.04.003Natural gas natural geographic society

Battin, T. J., Besemer, K., Bengtsson, M. M., Romani, A. M., \& Packmann, A. I. (January 01, 2016). The ecology and biogeochemistry of stream biofilms. Nature Reviews. Microbiology, 14, 4, 251-63.

Bousquet, P., Ciais, P., Miller, J. B., Dlugokencky, E. J., Hauglustaine, D. A., Prigent, C., ... White, J. (2006). Contribution of anthropogenic and natural sources to atmospheric methane variability. Nature, 443(7110), 439-443. https://doi.org/10.1038/nature05132

Cicerone, R. J., \& Oremland, R. S. (1988). Biogeochemical aspects of atmospheric methane. Global Biogeochemical Cycles, 2(4), 299-327. https://doi.org/10.1029/GB002i004p00299

Coleman, D. D., Risatti, J. B., \& Schoell, M. (1981). Fractionation of carbon and hydrogen isotopes by methane-oxidizing bacteria. Geochimica Et Cosmochimica Acta, 45, 7, 1033-1037.

Duarte, T. K. eo, Hemond, H. F., Frankel, D., \& Frankel, S.
(2006). Assessment of submarine groundwater discharge by handheld aerial infrared imagery: Case study of Kaloko fishpond and bay, Hawai'i. Limnology and Oceanography: Methods, 4(7), 227236. https://doi.org/10.4319/lom.2006.4.227

Dubey, S. K. (2005). Microbial ecology of methane emission in rice agroecosystem: A review. Applied Ecology and Environmental Research. https://doi.org/10.15666/aeer/0302

Etiope, G., Vadillo, I., Whiticar, M. J., Marques, J. M., Carreira, P. M., Tiago, I., ... Urresti, B. (2016). Abiotic methane seepage in the Ronda peridotite massif, southern Spain. Applied Geochemistry, 66, 101-113. https://doi.org/10.1016/j.apgeochem.2015.12.001

Farquhar, Graham D. Ehleringer, J. R. and H. K. T., Farquhar, G. D., Ehleringer, J. R., \& Hubick, K. T. (1989). Carbon Isotope Discrimination and Photosynthesis. Annual Review of Plant Physiology and Plant Molecular Biology, 40(1), 35. https://doi.org/10.1146/annurev.pp.40.060189.0024 $\underline{43}$

Fleeger, J. W., Carman, K. R., \& Nisbet, R. M. (2003), December 30). Indirect effects of contaminants in aquatic ecosystems. Science of the Total Environment. Elsevier. https://doi.org/10.1016/S0048-9697(03)00141-4

Freedman, B. (1995). Environmental ecology: The ecological effects of pollution, disturbance, and other stresses. San Diego: Academic Press.

Fry, B. (2006). Stable isotope ecology. Stable Isotope Ecology (pp. 1-308). Springer New York. https://doi.org/10.1007-0-387-33745-8

Grenier, M., Campeau, S., Lavoie, I., Park, Y. S., \& Lek, S. (2006). Diatom reference communities in Quebec streams (Canada) based on Kohonen self-organizing maps and multivariate analyses. Can. J. Fish Aquat. Sci., 63(9), 2087-2106.

Håkansson, S. (1985). A review of various factors influencing the stable carbon isotope ratio of organic lake sediments by the change from glacial to post-glacial environmental conditions. Quaternary Science Reviews, 4(2), 135-146. https://doi.org/10.1016/0277-3791(85)90017-4

Ide, S. T., Friedmann, S. J., \& Herzog, H. J. (2006). CO2 leakage through existing wells: current technology and regulations. 8th International Conference on Greenhouse Gas Control Technologies, 1-6. Retrieved from http://citeseerx.ist.psu.edu/viewdoc/download?rep=r ep1\&type $=$ pdf \&doi=10.1.1.208.1384

Jardine, T. D. D., McGeachy, S. a. A., Paton, C. M. M., Savoie, M., \& Cunjak, R. a. R. A. (2003). Stable Isotopes in Aquatic Systems: Sample Preparation, Analysis, and Interpretation. Fisheries and Aquatic Sciences, 2656(2656), 1-39.

Johnson, A. G., Glenn, C. R., Burnett, W. C., Peterson, R. N., \& Lucey, P. G. (2008). Aerial infrared imaging reveals large nutrient-rich groundwater inputs to the ocean. Geophysical Research Letters, 35(15). https://doi.org/10.1029/2008GL034574

Jones, R. I., Carter, C. E., Kelly, A., Ward, S., Kelly, D. J., \& 
Grey, J. (2008). Widespread contribution of methane-cycle bacteria to the diets of lake profundal chironomid larvae. Ecology, 89(3), 857864. https://doi.org/10.1890/06-2010.1

Jones, R. I., \& Grey, J. (2011, February). Biogenic methane in freshwater food webs. Freshwater Biology. https://doi.org/10.1111/j.1365-2427.2010.02494.X

Kang, M., Kanno, C. M., Reid, M. C., Zhang, X., Mauzerall, D. L., Celia, M. A., ... Onstott, T. C. (2014). Direct measurements of methane emissions from abandoned oil and gas wells in Pennsylvania. Proceedings of the National Academy of Sciences, 111(51), 18173-18177. https://doi.org/10.1073/pnas.1408315111

Kelly, M. G., \& Whitton, B. A. (1995). The Trophic Diatom Index: a new index for monitoring eutrophication in rivers. Journal of Applied Phycology, 7(4), 433444. https://doi.org/10.1007/BF00003802

King, G.E., King, D.E. (2013). Environmental risk arising from well-construction failure - Differences between barrier and well failure, and estimates of failure frequency across common well types, locations and well ages. SPE Production \& Operations, 28(4), 323-344.

Kiyashko, S. I., Narita, T., \& Wada, E. (2001). Contribution of methanotrophs to freshwater macroinvertebrates: Evidence from stable isotope ratios. Aquatic Microbial Ecology, 24(2), 203-207. https://doi.org/10.3354/ame024203

Konschnik, K., \& Jordaan, S., (2018) Reducing fugitive methane emissions from the North American oil and gas sector: a proposed science-policy framework, Climate Policy, DOI: 10.1080/14693062.2018.1427538

Krstic, S., Duma, A., Janevska, B., Levkov, Z., Nikolova, K., \& Noveska, M. (2002). Diatoms in forensic expertise of drowning - A Macedonian experience. Forensic Science International, 127(3), 198-203. https://doi.org/10.1016/S0379-0738(02)00125-1

Lavoie, I., Campeau, S., Darchambeau, F., Cabana, G., \& Dillon, P. J. (2008). Are diatoms good integrators of temporal variability in stream water quality? Freshwater Biology, 53(4), 827-841. https://doi.org/10.1111/j.1365-2427.2007.01935.x

Lavoie, I., Campeau, S., Grenier, M., \& Dillon, P. J. (2006). A diatom-based index for the biological assessment of eastern Canadian rivers: an application of correspondence analysis (CA). Canadian Journal of Fisheries and Aquatic Sciences, 63(8), 1793-1811. https://doi.org/10.1139/f06-084

Lavoie, I., Campeau, S., Zugic-Drakulic, N., Winter, J. G., \& Fortin, C. (2014). Using diatoms to monitor stream biological integrity in Eastern Canada: An overview of 10years of index development and ongoing challenges. Science of the Total Environment, 475, 187-200. https://doi.org/10.1016/j.scitotenv.2013.04.092

Lowry, C. S., Walker, J. F., Hunt, R. J., \& Anderson, M. P. (2007). Identifying spatial variability of groundwater discharge in a wetland stream using a distributed temperature sensor. Water Resources
Research, 43(10). https://doi.org/10.1029/2007WR006145

McNeely, C., Finlay, J. C., \& Power, M. E. (2007). Grazer traits, competition, and carbon sources to a headwater-stream food web. Ecology, 88(2), 391401. https://doi.org/10.1890/00129658(2007)88[391:GTCACS]2.0.CO;2

McPhillips, L. E., Creamer, A. E., Rahm, B. G., \& Walter, M. T. (2014). Assessing dissolved methane patterns in central New York groundwater. Journal of Hydrology: Regional Studies, 1, 57-73. https://doi.org/10.1016/j.ejrh.2014.06.002

Merritt, R. W., \& Cummins, K. W. (2008). An introduction to the Aquatic insects of North America. Dubuque, IA: Kendall/Hunt Pub. Co.

Minshall, G. W., Cummins, K. W., Petersen, R. C., Cushing, C. E., Bruns, D. A., Sedell, J. R., \& Vannote, R. L. (1985). Developments in Stream Ecosystem Theory. Canadian Journal of Fisheries and Aquatic Sciences, 42(5), 1045-1055. https://doi.org/10.1139/f85-130

National Petroleum Council (NPC). (2011). Plugging and abandonment of oil and gas wells https://www.npc.org/Prudent_DevelopmentTopic_Papers/225_Well_Plugging_and_Abandonment_Paper.pdf

NB, Department of Environment and Local Government, (2017, December). A Water Strategy for New Brunswick http://www2.gnb.ca/content/dam/gnb/Departments/ env/pdf/Water-Eau/WaterStrategyStrategieSurLeau/WaterStrategy-2018-2028.pdf

Osborn, S. G., Vengosh, A., Warner, N. R., Vengoshb, A., Warnerb, N. R., ... William Schlesinger, H. (2011). Methane contamination of drinking water accompanying gas-well drilling and hydraulic Methane contamination of drinking water accompanying gas-well drilling and hydraulic fracturing. Jackson Source: Proceedings of the National Academy of Sciences of the United States of America, 108(20), 8172-8176. Retrieved from http://www.jstor.org/stable/25830023 http://www.jstor.org/stable/25830023?seq=1\&cid=p df-reference\#references_tab_contents http://about.jstor.org/terms

Petersen, B. J., \& Fry, B. (1987). Stable Isotopes in Ecosystem Studies. Annu Rev Ecol Syst, 18(1987), 293-320. https://doi.org/10.1146/annurev.es.18.110187.00145 3

Poikane, S., Zampoukas, N., Borja, A., Davies, S. P., van de Bund, W., \& Birk, S. (2014). Intercalibration of aquatic ecological assessment methods in the European Union: Lessons learned and way forward. Environmental Science and Policy, 44, 237-246. https://doi.org/10.1016/j.envsci.2014.08.006

Post, D. M. (2002). Using stable isotopes to estimate trophic position: Models, methods, and assumptions. Ecology, 83(3), 703-718. https://doi.org/10.1890/00129658(2002)083[0703:USITET]2.0.CO;2

Rivard, C., Lavoie, D., Lefebvre, R., Séjourné, S., 
Lamontagne, C., \& Duchesne, M. (2013). An overview of Canadian shale gas production and environmental concerns. International Journal of Coal Geology.

https://doi.org/10.1016/j.coal.2013.12.004

Schuetz, T., \& Weiler, M. (2011). Quantification of localized groundwater inflow into streams using groundbased infrared thermography. Geophysical Research Letters, 38(3). https://doi.org/10.1029/2010GL046198

St. Peter, C. 2000. Oil shales and oil and natural gas in New Brunswick: Historical and current industry related activities. New Brunswick Department of Natural Resources and Energy, Minerals and Energy Division, Information Circular 2000-5, 14 p. http://www2.gnb.ca/content/dam/gnb/Departments/ en/pdf/Minerals-Minerales/ONG_History-E.pdf

Vannote, R. L. . ; G. W. Minshall ; K. W. Cummins. ; J. R.
Sedell (1980). The River Continuum Concept. NSF River Continuum Project., 130-137.

Whiticar, M. J. (1999). Carbon and hydrogen isotope systematics of bacterial formation and oxidation of methane. Chemical Geology, 161(1), 291-314. https://doi.org/10.1016/S0009-2541(99)00092-3

Whiticar, M. J., Faber, E., \& Schoell, M. (1986). Biogenic methane formation in marine and freshwater environments: $\mathrm{CO} 2$ reduction vs acetate fermentation - isotope evidence. Geochimica et Cosmochimica Acta, 50(5), 693-709. https://doi.org/10.1016/0016-7037(86)90346-7

Wallace, J. B., Webster, J. R., Meyer, J. L., Webster, J. R.,Strong, D. R., Nilsson, C. (1996). The role of macroinvertebrates in stream ecosystem function. Annual Review of Entomology, 41(5322), 115-39. https://doi.org/10.1146/annurev.en.41.010196.0005 55 